\title{
TRYNITARNOŚĆ ŚLADU (OBRAZU) BOGA W SUBSTANCJI BYTÓW STWORZONYCH
}

\section{THE TRINITARIAN TRACE (IMAGE) OF GOD IN THE SUBSTANCE OF CREATED BEINGS}

All religions deal with the question of the existence of God's divine image in creation. In Christianity, however, God's image has a Trinitarian dimension, which greatly enriches how one understands this issue. When noumenally considering God's image in creation, the first question at hand is the structure of the personal inner life of God, from which proceeds the form of God's creative act as well as the relationship between His divine trace and the existence of created beings. The fundamental prototype is the eternally begotten Son, the Holy Spirit who breathes through the Father and proceeds from the interior of the Father to the interior of the Third Person of the Trinity. The formation of the trace of God in the substance of created beings that have already been called into existence takes place through the mission of the Son and the Holy Spirit. The consequence of this action is the Trinitarian form of the energy of created beings, meaning the makeup of their inner substance. Along with this process, the relationship between God and created beings (both individually and collectively) and between created beings themselves is formed.

Key words: trace of God, image of God, God, creation, substance, relationship, Trinity, development, fulfillment. 


\section{Wstęp}

Ślad Boga istnieje w konkretnych jednostkowych substancjach w różny sposób. Inaczej w bytach personalnych (aniołowie, człowiek), inaczej w materii. Jest w całości, we wszechmaterii oraz w najbardziej subtelnych mikrocząstkach. Ślad substancji Boga odwzorowany jest za pośrednictwem energii. W substancjach duchowych jest to ślad Boskich właściwości personalnych: intelekt, wola, uczucia (zwłaszcza miłość). W materii jest ślad wewnątrzboskiego życia. Ogólnie można mówić o Boskiej pieczęci, która zakodowana jest w strukturze materii, w jej dynamizmie, w jej ruchu. Myśl chrześcijańska zawiera „coś” więcej, „coś” o pieczęci trynitarnej, zarówno w całości kosmosu, jak też w najbardziej subtelnych mikrocząstkach. Takim śladem, kodem, pieczęcią jest chociażby wirowanie: galaktyk, układów planetarnych, a z drugiej strony, atomów, wokół wspólnego środka ciężkości. Wirują też obiekty wokół swojej osi, zarówno gwiazdy i planety, jak też elektrony, czy super-mikroskopijne cząsteczki elementarne (spin). W stworzonych bytach duchowych można zauważyć trynitarną specyfikę aspektów personalnych. W intelekcie, uczuciach i woli jest coś ze specyfiki każdej z trzech Osób Boskich.

Substancja Boga jest nieporównywalnie inna od substancji stworzonych. Odległość bytowa między Bogiem a stworzeniami jest innego rzędu, niewyrażalna, niedająca się w żaden sposób wyobrazić. Tak samo wirowanie życia w Bogu jest nieskończenie potężniejsze od wirowania materii w najbardziej jej mikroskopijnym i najbardziej gigantycznym wymiarze. Bardziej fundamentalne pytanie, nieporównywalnie trudniejsze od pytania o kształt śladu Boga w świecie jest pytanie, o możliwość zaistnienia świata poza Bogiem oraz o możliwość bycia Boga poza sobą. Pytanie o ślad Boga w świecie pojawia się jako wtórne, aczkolwiek bardzo ważne. Z tą kwestią ściśle wiąże się pytanie o sposób tworzenia tego śladu przez Boga, a także o kształt relacji Boga ze światem. Sposób stwarzania świata, a tym samym, sposób tworzenia w nim śladu Boga, a także relacji, wynika ze specyfiki życia wewnątrz Boga. W ujęciu chrześcijańskim, źródłem jest życie trzech Osób Bożych.

\section{Tworzenie śladu Boga w substancji bytów stworzonych poprzez misje Syna i Ducha realizowane w świecie}

Życie Trójcy Świętej to życie wewnętrzne każdej z Osób oraz oddawanie się każdej z nich dwóm pozostałym i przyjmowanie przez każdą z nich dwóch pozostałych. Trojaka wsobność i trojaka otwartość odczytywana jest z Objawienia, a następnie rozjaśniana przez refleksje nad wzajemnym odniesieniem specyfiki jednostkowej z całością Misterium Boga. Tajemnica osoby to jednocześnie 
istniejące otwarcie, dzielenie się oraz posiadanie czegoś swojego, co przekazane być nie może. Odnosi się to do wszelkich osób: ludzkich, anielskich i Boskich. Osoby Boskie różnią się od osób stworzonych tym, że są absolutne, a tym samym są w jednej tylko substancji, ponieważ substancja absolutna może być tylko jedna. We wszelkich bytach stworzonych jest ślad specyfiki personalnej Ojca, Syna i Ducha Świętego, jest ślad rodzenia Syna przez Ojca, i przechodzenia Ducha Świętego od Ojca do siebie, jest ślad wszystkiego tego, co dokonuje się we wnętrzu Boga Trójjedynego. Ślad Boży jest ze swej istoty personalny. Oznacza to, że nawet byty nie-personalne mają w sobie coś z personalności: swoją własną specyfikę, relacyjność i otwartości, a inne byty: stworzone i niestworzone. Taka też musi być relacja między Bogiem a nimi. Początkiem jej jest sam Bóg, a końcem byty stworzone. Tym samy, cały świat jest w jakiś sposób zakorzeniony w Bogu, z Niego wynika i do Niego zmierza. W takiej samej mierze, w jakiej Bóg jest w świecie, świat jest w Bogu. Nie ma radykalnego oddzielenia i nie ma zmieszania. Z całą pewnością wszędzie jest trynitarność w stopniu analogicznym, na miarę daną poszczególnym stworzeniom. Refleksja teologiczna na ten temat ogarnia z jednej strony, trynitologię, a z drugiej, całą wiedzę o świecie: objawioną i naturalną.

Zupełnie nie można pojąć tego, w jaki sposób w Bogu jest coś, co odpowiada początkowi świata. Patrząc na świat, możemy zastanawiać się nad tym jak długo istnieje (w mierze czasu, jaką my dysponujemy). Można przyjąć, że świat ma początek. Sam punkt początkowy jest niedostępny dla badań, a nawet dla ludzkiej myśli. Można jednak powiedzieć, że jeżeli świat istnieje określoną ilość czasu, np. czterdzieści miliardów lat, to czterdzieści jeden miliardów lat temu nie istniał. Nie możemy jednak przykładać kategorii doczesnych do wiecznego bytowania Boga. W Bogu nie ma czasu, nie ma punktu, w którym zaktualizował decyzję stworzenia świata. Każdy czyn wewnątrz Boga jest wieczny. Stąd świat mógłby istnieć wiecznie, i nie byłoby to sprzeczne z transcendencją Boga. Prawda o początku świata jest tożsama z prawdą, że świat nie jest Bogiem. Nie można wyjaśnić tego, jak wnętrze Boga odzwierciedla się na zewnątrz substancji Boga. Można mówić o każdym z dwóch biegunów, o akcie stwórczym i jego skutku, ale o sposobie pojawienia się świata wiemy tylko tyle, że jest on trynitarny. Wyraźnie widoczne jest to w opisie Wcielenia. Equangelia według Łukasza mówi o czynie Boga i jego skutku, nie wspominając o tym, w jaki sposób to się stało. Tak też jest z przejściem człowieka z tego świata do wieczności. Człowiek od razu jest w niebie, czyśćcu lub piekle. Nic nie możemy powiedzieć o momencie przejścia, o sposobie przechodzenia. Punkt styku pozostaje w mrokach tajemnicy. Natomiast zawsze można i trzeba mówić o strukturze trynitarnej. Takie jest życie wewnątrz Boga, taki jest akt stwórczy, taki jest jego skutek, taka jest relacja Boga do świata (i wzajemnie), takie jest 
działanie Boga w świecie, taki jest ślad Boga w stworzeniach. Ślad ten tworzony jest przez misje Syna i Ducha w świecie, które są odwzorowaniem tego, co Syn i Duch czynią wewnątrz substancji Bożej.

Substancja Boga jest otwarta na wszelkie stworzenia, w szczególności na ludzi. Ślad Boga w stworzeniach polega na tym, że są one otwarte na inne stworzenia, są relacyjne. Trzeba o tym mówić. Radykalny apofatyzm w tym względzie, czy w jakimkolwiek innym zagadnieniu, jest postawą bliską deizmowi, który nie podejmuje zagadnienia relacji. Stąd już krok do tego, by w ogóle nie mówić o Bogu, a to zbliża się do ateizmu. Tymczasem Bóg Stworzyciel jest też Bogiem Objawienia. Jedno i drugie polega na wychodzeniu Boga na zewnątrz swojej substancji. Stąd postulat powiązania trynitologii z chrystologią, eklezjologią, jak również z teologią historii. Ślad Boga jest nie tylko wewnątrz stworzeń, lecz również w ich wzajemnych relacjach oraz w działaniu, które dokonuje się w czasie i przestrzeni. W bytach personalnych rdzeniem śladu Boga jest intelekt, wola i uczucia. Ślad Boga nie jest czymś statycznym, lecz zawiera w sobie impuls powodujący ruch. Wyższą formą śladu Boga jest życie: roślinne, zwierzęce, personalne. Koniecznym wymiarem wyposażenia personalnego jest dynamizm, działanie. Rezygnacja z działania intelektu, uczuć i woli oznacza zanik personalności. W szczególności dotyczy to wiary, której początkiem jest przekonanie o prawdziwości poznanego orędzia. Zanik Kościoła w krajach dotąd chrześcijańskich wynika nie tylko z braku realizacji poznanych prawd wiary w życiu, lecz z braku znajomości treści Objawienia. Samo poznanie intelektualne nie wystarcza, ale gdy go nie ma, nie może być życia wiary. Odnowa życia rozpoczyna się od poznania intelektualnego. Panuje przekonanie, że wszyscy wszystko wiedzą i na tym się zatrzymują. W rzeczywistości tak nie jest i trzeba zaczynać od fundamentów.

Konieczne jest poznawanie tych treści wiary, nad którymi rozpościera się zasłona nałożona przez ludzi. Trzeba poznać komplet prawd wiary, a następnie utworzyć wielowymiarowy model teologiczny lączący wszystkie aspekty. Próbujemy wcielać w życie różne fragmenty wiary, ale brak poznania całości sprawia, że świadectwo życia też nie jest integralne. Troska o łączenie doktryny z praktyką przynosi właściwe skutki wtedy, gdy sama doktryna jest pełna, integralna, wewnętrznie spójna. Za pośrednictwem objawienia, jego odczytywania i refleksji nad nim, ślad Boży zawarty w życiu wszystkich ludzi staje się coraz mocniejszy. Powinny być głoszone wszelkie elementy Objawienia oraz ich wzajemne powiązania, tworzące organiczną całość. Nie wystarczy ideologia, czyli budowanie mozaiki złożonej z pojęć, których nikt nie rozumie. Trzeba te pojęcia wyjaśniać. Przede wszystkim trzeba mówić o rzeczywistej treści Objawienia, posługując się różnymi pojęciami, aby wypowiedzieć możliwie najwięcej. Tego rodzaju wyjaśnianie dokonuje się już w działaniu Boga, który 
przychodzi, jest wśród nas i mówi do nas. Osoby Boże wchodzą w świat nie po to, aby przynosić dodatkowe pytania bez odpowiedzi, aby zwiększyć ilość niezbadanych tajemnic, lecz po to, aby pytania dotyczące Boga i świata rozjaśnić, aby dać przejrzystą odpowiedź - na miarę ludzkich możliwości. Objawienie jest śladem życia i wiedzy Boga. Teologia to kolejne odwzorowanie - w umysłach ludzi. W całości ludzkiej egzystencji znajduje się ślad (odwzorowanie, obraz) ludzkiej myśli, a ostatecznie ślad Boga. Im pełniejsza teologia, tym pełniejsze może być całe życie ludzkie. Centralne miejsce w teologicznej refleksji zajmuje chrystologia, czyli refleksja o Jezusie Chrystusie, jedynym Pośredniku, w którym świat coraz bardziej zbliża się do swego ideału ${ }^{1}$.

Poza chrześcijaństwem, refleksja teologiczna prowadzi do aporii. Każda kolejna próba wyjaśniania prowadzi do kolejnych pytań, do niedających się rozwiązać zagadek. Wszystkie aporie przezwycięża teologia chrześcijańska, oczywiście - całościowa, systematyczna, dogłębna i spójna. Wybiórczość, pomijanie czegoś, zostawianie „białych plam” sprawia, że staje się to niemożliwe. Uwagi te nie są zachętą do dowolności, do wymyślania dowolnych interpretacji. Wręcz odwrotnie, przypominają o rzetelnym odczytywaniu Objawienia i rzetelne refleksji, która pogłębia, i systematyzuje wiedzę. Nowa teologia musi być integralna, musi być jeszcze bardziej ortodoksyjna, jeszcze bardziej wierna. Trzeba otworzyć się na pełnię Objawienia, nie tylko na wszystkie prawdy, lecz na pełnię ich wymiarów ${ }^{2}$. Fundamentalny ślad Boga jest wszędzie, w całym świecie, ale od jakości teologii zależy dojście do pełni. Integralność oznacza uwzględnienie wszystkich aspektów i pełnię życia.

W Bogu Osoby kipią życiem na miarę absolutu, przechodzą wzajemnie do siebie i nieustannie, bezczasowo wirują, każda w sobie, i wszystkie razem, w jednej substancji absolutnej. Przechodzą wzajemnie do siebie (circumincessio), przebywają wzajemnie w sobie (circuminsessio), będąc Jednym Bogiem. Trynitarne przechodzenie ma określony kształt, wynikający z trzech specyficznych właściwości personalnych (pochodzenia, relacje). Tak samo jest z przechodzeniem do świata i przebywaniem w nim. Misje Syna i Ducha stwarzają świat, pozostawiają w nim swój ślad i prowadzą do pełni. W świecie, a zwłaszcza w stworzonych substancjach duchowych, odzwierciedla się Boskie wirowanie. Na miarę stworzeń odzwierciedla się absolutny, bezczasowy wybuch życia. Misje Osób Bożych w świecie przebiegają od początku do końca świata, wnikając w każdy moment czasu i w każde miejsce, zakreślając krąg dziejów, który styka się z bezczasowością wieczności. Bóg w świecie jest wszędzie i zawsze. Hiszpański teolog, Nereo Silanes, mówiąc o działaniu Osób Boskich w świecie,

Por. N. Ciola, Teologia trinitaria. Storia-metodo-prospettive, Bologna 1996, s. 26.

Por. ibidem, s. 28. 
stosuje termin „przedłużenie”. Pochodzenia trynitarne, wieczne, przedłużają się w stworzeniach, zwłaszcza w bytach rozumnych. W ten sposób dynamizm dziejów ludzkości splata się z dynamizmem Boga Trójjedynego 3 .

Powszechny w świecie ruch wirowy bardziej pasuje do Boga Trójjedynego, natomiast ruch linearny pasuje do Boga, który jest tylko jedną Osobą. Z tego wynika, że w teologii chrześcijańskiej myślenie kategoriami geometrii Euklidesa powinno być zastąpione sposobem myślenia charakterystyczny dla geometrii Riemanna czy Łobaczewskiego. Odpowiednio też, sposób myślenia kosmologii Arystotelesa i Newtona powinien być zastąpiony sposobem myślenia charakterystycznym dla Alberta Einsteina. Teologia to mówienie o Bogu i sprawach Bożych językiem ludzkim, jak najbardziej adekwatnym. Język ten powinien być ubogacany, tym bardziej wtedy, gdy pojawia się język bardziej adekwatny, którym można lepiej wypowiedzieć objawione Misterium. Okazuje się, że dziś odkrycia naukowe i ogólna myśl ludzka dostarczają pojęć, metafor, koncepcji, które są bardziej adekwatne dla Objawienia chrześcijańskiego. Tymczasem teologowie tego nie zauważają, terminy czerpane z języka potocznego i z różnych dyscyplin naukowych ciągle wyrażają „po staremu”. Skutkiem tego jest duszenie wiary chrześcijańskiej i powracanie do schematu, który bardziej odpowiada Staremu Testamentowi. Brak otwarcia się teologii oraz brak integralności, to ważna przyczyna zaniku wiary w wielu krajach. Teologowie, chcąc się wykazać, głoszą tezy niezgodne $z$ wiarą chrześcijańską. Tymczasem mogą wykazywać swoje umiejętności podejmując zagadnienia istotne, a zepchnięte na margines, pomijane, przemilczane. Narzędziem pomocnym w odbudowaniu wiary chrześcijańskiej jest właściwa refleksja rozumu ludzkiego nad treścią Objawienia.

Bóg Ojciec stwarza i rozwija ślad boskiego życia poprzez misje Syna i Ducha. Sprawowanie władzy monarchicznej nad światem przez Trójcę Świętą oznacza dawanie istnienia, podtrzymywanie $w$ istnieniu i rozwijanie. Już w pierwszych wiekach chrześcijaństwa odróżniano refleksję nad wewnętrznym życiem Boga, a nad życiem i działaniem Boga w świecie. W tym kontekście, dyskutując z Hermogenesem, Tertulian odróżniał terminy „Deus” i „Dominus”. Gdy mówił tylko o Bogu, stosował termin „Deus”, a gdy mówił o monarchii Boga wobec świata, stosował termin „Dominus”. Tytuł ten odnosi się do wszystkich trzech Osób Boskich ${ }^{4}$. Według Tertuliana, monarcha Boga wobec świata ma na celu zbawienie świata, które dokonuje się poprzez misje Syna i Ducha, czyli poprzez realizowanie ekonomii zbawczej. Zmieniając zwrot refleksji, skutki działania

3 Por. N. Silanes, Misión, misiones, [w:] X. Pikaza, N. Silanes (red.), Diccionario Teológico. El Dios cristiano, Salamanca 1992, s. 886.

4 Por. G. Uríbarri Bilbao, Monarquia y Trinidad, Publicaciones de la Universidad Pontificia Comillas. Madrid, serie I: Estudios 62. wyd. UPCO (Universidad Pontificia Comillias), Madrid 1996, s. 184. 
Boga w świecie prowadzą człowieka wierzącego do refleksji nad życiem wewnętrznym w Bogu, a ostatecznie do wniosku o istnieniu substancji Boga, jednej jedynej, ale trynitarnej ${ }^{5}$. W ten sposób, monarchia i ekonomia wyrażają zarazem jedność oraz troistość w Misterium Boga.

Wewnątrz Boga monarchia oznacza, że Ojciec jest źródłem Syna i Ducha, którzy nie wyłaniają się z substancji absolutnej - nieokreślonej, lecz z Osoby Ojca, aczkolwiek nie z właściwości personalnych rozumianych abstrakcyjnie, lecz z Ojca, który jest substancją absolutną - ojcowską. Zawsze trzeba pamiętać, że osoba to nie tylko specyficzne przymioty, lecz realnie istniejąca we wszystkim substancja duchowa. Błędem jest przechodzenie od mówienia reistycznego do mówienia wyłącznie o jaźni, czy wskazywanie tylko na osobowość. Mówienie o osobie wymaga uwzględnienia wszystkich aspektów. Dziś nie mówi się nic o substancji, również w teologii. Zdecydowanie trzeba powrócić do refleksji o substancjach duchowych oraz o energiach duchowych. W tej sytuacji przez wielu przyjmowana jest formuła Barucha Spinozy (zm. 1677), który nadawał substancji materialnej w jej całości cechy boskie: Deus sive natura sive substantia $($ Bóg $=$ przyroda $=$ substancja $)$. Boska materia jest jednocześnie źródłem emanacji (natura naturans), jak i jej efektem (natura naturata). Poznawanie przyrody oznacza poznawanie Boga ${ }^{6}$.

W ujęciu chrześcijańskim Bóg jest transcendentny wobec świata. Poznawanie Boga żyjącego poza światem jest możliwe dzięki temu, że człowiek jest stworzony na obraz Boga. Poznanie to jest jednak istotnie ograniczone, nie można poznać Boga w całej pełni. Wyrażenie prawdy o Bogu dokonuje się za pomocą metody zwanej analogią, która wskazuje na Boga, ale nie potrafi mówić o Nim adekwatnie ${ }^{7}$. Przede wszystkim, gdy używane są terminy zaczerpnięte ze świata przyrody, to ich zawartość powinna być jak najpełniejsza, jak najbardziej zgodna z najnowszymi odkryciami różnych nauk. Dzięki temu lepiej odczytujemy objawienie, które dokonuje się w tym świecie, mówi nie tylko o Bogu, lecz również o świecie i wyrażane jest za pomocą języka z tego świata.

Wśród wszystkich bytów stworzonych, które są odskocznią dla refleksji o Bogu, naczelną rolę odrywa człowiek. Nic więc dziwnego, że w dziejach refleksji o Bogu wielką rolę odgrywają antropomorfizmy, czyli wyobrażanie sobie Boga według tego, co wiemy o człowieku. Tego rodzaju obrazy zawierają się również w Piśmie Świętym. Trzeba je rozumieć w kontekście całości

Por. ibidem, s. 189.

6 Zob. W. Breuning, Nauka o Bogu, Podręcznik Teologii Dogmatycznej. Traktat II, (red. W. Beinert), Kraków 1999, s. 96.

7 Por. J. Misiurek, Antropomorfizm III. W teologii, [w:] Encyklopedia Katolicka, t. 1, red. F. Gryglewicz, R. Łukaszyk, Z. Sułowski, Lublin 1985, kol. 703. 
objawienia ${ }^{8}$. Również w tym przypadku obowiązuje zasada ulepszania języka przez lepsze rozumienie człowieka w ogóle, a zwłaszcza tego, co o człowieku mówi Bóg objawiający się. Niestety, teologiczne słowa interpretowane są tak, jak to czyniono w Starym Testamencie, albo w starożytnej filozofii, czy w starożytnych naukach przyrodniczych. Dziś trzeba czerpać z najnowszych osiągnięć nauk przyrodniczych i humanistycznych, ale przede wszystkim z Nowego Testamentu, zwłaszcza z antropologii wynikającej z wydarzenia Zmartwychwstania. Bezpośrednim wnioskiem ze zmartwychwstania Jezusa Chrystusa jest istnienie substancji (!) duchowej człowieka. Z tego względu antropomorficzne mówienie o Bogu też powinno kierować myśl ku prawdzie, że Bóg jest substancją, oczywiście transcendentną, absolutną, ale substancją, a nie abstrakcyjnym obrazem. Ślad Boga w substancjach stworzonych prowadzi do refleksji nad Pierwowzorem, który znajduje się w substancji Boga.

Wszelkie ograniczenia, zawężenia, rozgraniczenia, czy - odwrotnie - wymieszanie dokonywane w refleksji nad stworzeniami prowadzi do analogicznych błędów w refleksji nad Bogiem. Odrzucenie autonomii substancji materialnej i duchowej w człowieku świadczy o myśleniu mieszającym, które prowadzi do zmieszania Boga ze światem. Tego rodzaju pokusy mają niektórzy filozofowie żydowscy oraz islamscy, ale też chrześcijańscy, którzy nie do końca uświadomili sobie nowości Equangelii. Przykładem są myśliciele hiszpańscy z IX wieku, przedstawiciele Kościoła mozarabskiego: Hostigesios, Romano i Sebastián. Wprowadzili oni antropomorfizmy do nauczania o Trójcy Świętej i przedstawiali Ją w sposób plastyczny, materialny. Według nich, substancja Boga jest subtelnie wymieszana z substancją bytów materialnych (per subtilitatem quamdam) ${ }^{9}$. Okazuje się jednak, że mówienie o subtelnym wymieszaniu, czy o subtelnej materii nie wyjaśnia zagadnienia jedności z zachowaniem autonomii. Słusznie więc ich pogląd był zwalczany i odrzucony. Między innymi, herezję tę zwalczał opat Samson, który w roku 862 przedstawił biskupom zebranym w Kordobie wyznanie wiary trynitarnej, porównując je z tekstami Pisma Świętego i z nauczaniem Ojców Kościoła. Opat Samson mówił o jedności Boskich Osób w jednej esencji, o człowieczeństwie Chrystusa i o jedności dwóch natur w Jego Osobie, o Wcieleniu oraz o obecności Boga we wszystkich rzeczach. Podkreślał on mocno, że Bóg napełnia, zachowuje i otacza wszystko nie na sposób ciał materialnych, lecz w sposób niecielesny i niewidzialny. Krytykował on zwłaszcza

8 Por. ibidem, kol. 704: „antropomorfizm znajduje zastosowanie w powszechnym nauczaniu prawd wiary, zwłaszcza w środowiskach wymagających przystępnego podania nauki o Bogu".

9 Por. A. Bayón, La teología en la España de los siglos VIII-X, [w:] Historia de la Teología Española, t. 1: Desde sus orígenes hasta fines del siglo XVI, M. A. Martinez (red.), Madrid 1983, s. 360. 
pogląd Hostigesisa, że Bóg dosłownie przyjmuje różne postacie materii, na podobieństwo ducha materialnego u stoików i u Arystotelesa. Opat Samson zwalczał ten pogląd mówiąc, że Bóg nie jest subtelną materią, lecz bytem innego rodzaju, niematerialnym, że mamy do czynienia z substancją duchową, transcendentną wobec materii. Subtelność Boska jest tożsama z istotą, jest niezmienna, wieczna, absolutna. Nie ma nic wspólnego z jak najbardziej subtelną materią. Przebywanie Boga w bytach stworzonych i dostosowanie działania do danego bytu wynika z bogactwa zapisanego w zamyśle Bożym, nie polega na przyjmowaniu postaci materialnej ${ }^{10}$. Błędne myślenie w Hiszpanii w IX wieku, dotyczące śladu Bożego w substancjach stworzonych, było skutkiem wpływów islamu, który pojawił się w VII wieku na Wschodzie, pod wpływem syryjskich i chaldejskich wypaczeń wiary chrześcijańskiej, w ramach wielkiego nurtu nestoriańskiego. Nestorianizm oddziaływał na myślicieli hiszpańskich za pośrednictwem islamu, ale też bezpośrednio, ze strony Syryjczyków-nestorian, którzy osiedlili się w Lewancie, na południu Hiszpanii. Z tej mieszanki kulturowej i religijnej wyłaniały się ciągle nowe herezje, z których najgroźniejsze były herezje chrystologiczne. Chrystus - jak w islamie - uważany był tylko za człowieka, za wielkiego proroka, ale tylko człowieka ${ }^{11}$. Wszelkie herezje, a zwłaszcza ich mieszanka, prowadziły w taki czy inny sposób do panteizmu, czyli odrzucenia substancji duchowej, transcendentnej wobec materii.

Obecność substancji Boga w całym stworzonym uniwersum dokonuje się za pośrednictwem energii. Bezpośrednio ślad Boga w stworzeniach tworzony jest przez energie Boże, przede wszystkim przez energie personalne Syna i Ducha. Odwieczne pochodzenia trynitarne odzwierciedlone są w akcie stwórczym, a tym samym również w skutku tego Boskiego czynu, czyli w bytach stworzonych i w relacjach wiążących stworzenia z Bogiem. Skutkiem aktu stwórczego jest też przestrzeń i czas, a tym samym sposób działania substancji stworzonych w czasoprzestrzeni. Ekonomia zbawcza odzwierciedla wewnętrzne życie Boga w materii, czasie i przestrzeni. Z tego wynika, że myśl ludzka może poznać obecność Boga w świecie po skutkach działania zbawczych misji trynitarnych (S. Th. I, 43, 2 ad 3). Poznając, człowiek otwiera się na działanie Boga i wchodzi w obszar życia Bożego ${ }^{12}$. Poznanie Trójcy Świętej w jej intymnym życiu Bożym dokonuje się poprzez poznanie manifestacji historycznych. Uczestniczenie w intymnym życiu Trójcy Świętej dokonuje się poprzez uczestniczenie w boskim działaniu dokonującym się wewnątrz dziejów świata, a zwłaszcza

10 Por. ibidem, s. 361.

11 Por. ibidem, s. 362.

12 Por. J. Ferrer Arellano, Los dos manos del Padre. El doble movimiento de la alianza salvífica, en la misión conjunta e inseparabile del Verbo y del Espíritu Santo, como „incarnatio in fieri”, "Annales Theologici" 13 (1999s. 19. 
w historii ludzkości. Czyny utwierdzają w człowieku energię Boską, tym samym wzmacniają relację z Bogiem Trójjedynym, a ostatecznie - z substancją Boga.

\section{Wyposażenie stworzeń w energie Boskie}

Stworzenia wskazują na Boga Stworzyciela. Akt stwórczy nie jest dosłownym przedłużeniem wewnętrznego życia trynitarnego, jak to głoszą niektórzy teologowie ${ }^{13}$, lecz dokonuje się wewnątrz Boga. Przedłużenie wnętrza Boga w świecie ma charakter analogiczny, jest jakaś relacja, ale jest też przepaść ontyczna między Bogiem a światem. Osoby Boże w niczym się nie zmieniają po stworzeniu świata w tym, co stanowi ich boskość. Nowością jest promieniowanie na zewnątrz substancji boskiej, przebywanie w stworzeniach i działanie w nich. Ślad Boży jest czymś pośredniczącym i wyjaśniającym sposób jednoczenia się Boga ze światem. Można coś poznać, ale tylko fragmentarycznie, w takiej mierze, w jakiej można poznać więź obrazu Bożego z Bogiem, a z drugiej strony $-z$ substancjami stworzonymi. Ślad Boży jest to jakiś schemat, kształt, mądrość stworzona, która jest odwzorowaniem Mądrości niestworzonej. Czymś więcej jest obraz Boży w stworzeniach duchowych. Jest nim już nie tylko schemat, lecz realne wyposażenie wewnętrzne, a nawet substancja duchowa, która nie tylko ma w sobie obraz Boży, ale jest nim w swej całości. Kosmos to świat uporządkowany mnogością wzajemnych relacji. Sieć relacji sprawia jedność wszechświata. „Najważniejsze są relacje konieczne i transcendentalne, które obecne są w każdym bycie przygodnym. Do tego dochodzi nieprzeliczalna ilość relacji niekoniecznych, którymi ubogaca się jedność rzeczywistości"14. W sferze materialnej jest to jedność bezpośrednia, pełna, natomiast w sferze bytów stworzonych duchowych jest to jedność pośrednia. Substancje duchowe stworzone są jednoczone horyzontalnie - za pośrednictwem energii duchowych stworzonych oraz wertykalnie - mocą energii niestworzonej, mocą energii Boga Trójjedynego.

Stworzenie człowieka to pojawienie się nowej substancji, różnej od materii, a także od substancji aniołów. Złączenie się substancji duchowej ludzkiej z ciałem oznacza, że w ramach materii pojawia się nowa jakość, pojawia się ciało ludzkie, którego formą jest dusza. Nie tylko dusza, lecz również ciało ma w sobie obraz Boży. W kontekście stworzenia człowieka, materia jest rozumiana inaczej, na istotnie wyższym poziomie bytowym, niż materia nieożywiona, niż rośliny, a nawet zwierzęta. Ciało ludzkie jest istotnie wyższego rzędu niż

13 Zob. B. de Margerie, Osoba ludzka śladem, obrazem i podobieństwem Boga Trójcy, [w:] Tajemnica Trójcy Świętej, Warszawa - Poznań 2000, s. 389

14 Zob. M. A. Krąpiec, Analogia, [w:] Powszechna Encyklopedia Filozofii, t.1, Lublin 2000, 210-220. 
ciało zwierzęcia. Po zmartwychwstaniu ciało ludzkie otrzymuje swoją pełnię. Zmartwychwstanie jest też wyniesieniem duszy do sytuacji pełni. Wydarzenie to podnosi człowieka do rangi stwórcy. Dusza włączona jest w działanie Osób Bożych w akcie stwarzania nowego życia. W akcie poczęcia dziecka cielesność rodziców daje budulec dla nowego ciała, ale życie daje mu tylko Bóg, stwarzając duszę. Zmartwychwstanie polega na tym, że Bóg daje duszy moc współuczestniczenia w stwarzaniu życia nowego ciała. Dzięki temu obraz Boży w człowieku dochodzi do pełni. Pełna jest też energia personalna. W ten sposób substancja ludzka - duchowa i materialna - znajduje się w Boga w stopniu najwyższym, jaki jest przewidziany dla stworzeń.

Bóg stwarza wypowiadając słowa we wnętrzu swojej substancji. Są to dwa sposoby wypowiadania się Ojca: rodzenie i tchnienie, które wydobywają odwiecznie Syna i Ducha, a także dwie Osoby: rodzona i tchniona, czyli Syn Boży i Duch Święty. Każda z Osób jest Logosem, wypowiadającym i wypowiadanym, aczkolwiek termin ten jest nazwą własną tylko w odniesieniu do Syna Bożego. Tak samo każda z Osób jest Duchem i jest Święta, ale termin Duch Święty jest nazwą własną trzeciej Osoby Trójcy. Ślad Boży jest odzwierciedleniem boskiego rodzenia i tchnienia sprawiając, że struktura materii umożliwia pojawienie się życia, a także potrafi (zorganizowana w postać ciała człowieczego) przyjmować promieniowanie duchowe i zjednoczyć się z ludzką substancją duchową w jedną całość personalną.

Ontycznym początkiem świata nie jest słowo w sensie pojęcia, idei, lecz $\mathrm{w}$ sensie personalnego wypowiadania się Boga w swoim intymnym wnętrzu. Idea świata tkwiąca w zamyśle Bożym nie pojawia się na zewnątrz substancji Boga (mądrość stworzona) sama, bez materii, lecz razem z materią, a następnie razem z substancjami duchowymi. Ślad Boży, obraz Boży i łaska nie są między Bogiem a bytami stworzonymi, lecz w nich. Są one skutkiem działania Bożego, włożonym w byty stworzone, są źródłem samodzielnego istnienia, życia i personalnego działania. Obraz Boży w człowieku jest źródłem języka ludzkiego, wnikającego w świat, który sam w sobie jest już swoistym językiem, aby w ten sposób skuteczniej poznawać Boga, stworzyciela osób ludzkich i całego świata. Megajęzyk to nie tylko słowa pojawiające się w ludzkim intelekcie i artykułowane na zewnątrz, lecz wszystko: kształty, działania, struktury, wszelka stworzona substancja, to język mówiący o Stworzycielu, to język, poprzez który Stworzyciel przemawia do ludzi ${ }^{15}$. Język ten jest naukowy i poetycki, precyzyjny i piękny, informujący i życiodajny, ukazujący, że piękno bytów powiązane jest $z$ dobrem, sensem i prawdą. Dzięki temu, człowiek poznaje odzwierciedlenie Boga w kosmosie i w sobie (vestigium Dei - obraz Boży), a także rezonans

15 Por. M. R. Capellini, André Neher e l'ermeneutica biblica, „Studia Patavina” 46 (1999) nr 1, s. 113. 
między poziomami bytowymi: pomiędzy stworzeniami, a nade wszystko między całym światem, a Bogiem. Odnoszenie bytów stworzonych do Stwórcy tworzy drogę, która jest nie tylko skierowana ku Bogu, lecz wnika w Jego wewnętrzną prawdę. Człowiek poznaje drgania życia Boga w bytach stworzonych, a tym samym poznaje drgania życia wewnątrz-boskiego ${ }^{16}$.

Każda substancja stworzona zawiera w sobie pierwiastek boski, dany w akcie stwórczym i decydujący o relacji z Bogiem. Stworzenia nie są Bogiem (Theós), ale mają boskość (theótes), według swojej miary, według miary istnienia ${ }^{17}$. Bóg sprawia, że całe uniwersum bytów jest Boskie ${ }^{18}$. W systemie Dionizego Pseudo Areopagity cała hierarchia bytów stworzonych jest Boska (therchía), tworząc konstelację spójną w sobie i zespoloną ze Stworzycielem. Dionizy stara się wyjaśnić, w jaki sposób moc Boga wchodzi w całość wszechświata, podtrzymując go w istnieniu. Troska Boga o świat (opatrzność; prónoia) zapewnia istnienie i rozwój, skierowany ku Bogu i zmierzający do określonej dla danego bytu pełni. Relacja Boga ze światem nie jest abstrakcją, lecz czymś realnym, i to nie statycznym, lecz dynamicznym, coraz mocniej zanurzanym w dynamizmie życia Bożego nie tylko od strony Stwórcy, lecz również od strony świata ${ }^{19} . \mathrm{Z}$ tego wynika, że ślad Boży tkwi w substancjach, ale też w relacjach, w złożonej sieci relacji zespalającej różne byty stworzone w jedną całość i jednoczącej z bogactwem wewnętrznego życia Bożego.

\section{Relacja śladu Bożego w bytach stworzonych z życiem wewnętrznym Osób Bożych}

Substancja Boga jednoczy z sobą substancje stworzone za pośrednictwem troistej energii absolutnej - personalnej, która w sposób bezpośredni styka się $z$ energią bytów stworzonych. W odniesieniu do bytów stworzonych - personalnych relacja ma charakter personalny z obu stron i może się rozwijać, wzmacniać. Tym samym, może się rozwijać trynitarność tej relacji. Relacja śladu Bożego w bytach stworzonych z życiem wewnętrznym Osób Bożych nie wnika głęboko do wnętrza tych bytów. W bytach personalnych Bóg działa bardziej od wewnątrz. Działanie energii niestworzonych splata się z energią personalną tych bytów, prowadząc do osiągnięcia przez nie pełni personalności. Efektem działania energii boskich niestworzonych jest energia boska stworzona, czyli

\footnotetext{
16 Por. ibidem, s. 114.

17 Por. V. Muñiz Rodriguez, Nombres de Dios, [w:] X. Pikaza, N. Silanes (red.), Diccionario..., s. 970.

18 Por. ibidem, s. 971.

19 Por. ibidem, s. 972.
} 
łaska, która pobudza intelekt, uczucia i wolę (łaska uczynkowa), a nawet wprowadza relację człowieka z Bogiem na istotnie wyższy poziom (łaska habitualna, czyli Boski element natury ludzkiej). W ten sposób natura ludzka jest jednocześnie naturalna (w swoim niezbywalnym, fundamentalnym podłożu) i nadnaturalna: ludzka, i Boska. Boskość człowieka nie jest identyczna z boskością Boga, jest tylko jej obrazem, odwzorowaniem, czymś analogicznym, na miarę bytu stworzonego, a dokładniej - na miarę substancji stworzonej. Substancja stworzona jest ograniczona, nie jest absolutna, ogranicza ontyczne znaczenie posiadanej przez siebie energii Boskiej. Nawet w Synu Bożym Wcielonym energia Boska stworzona nie miesza się z energią niestworzoną. Umacnianie relacji ludzi z Bogiem dokonuje się za pośrednictwem Chrystusa, w Kościele, poprzez sakramenty ${ }^{20}$.

Dla zaistnienia relacji muszą być obiekty różne, ale mające w sobie odpowiednią otwartość. Nie istnieje kwestia relacji Boga ze światem w panteizmie. W manicheizmie jest totalna odrębność. Teizm uznaje jednoczesne istnienie autonomii oraz relacji. Relacja Boga ze światem jest zagadnieniem fundamentalnym w każdej religii, uznającej istnienie Boga transcendentnego wobec świata. W Bogu jest odwieczny zamysł Boży, który nie tylko jest planem, wzorcem, ale otwartością. Plan świata znajduje się wewnątrz Boga, Jego istotnej właściwości personalnej - w otwartości, która konkretyzuje się w trzech Osobach, otwartych na siebie nawzajem w sposób absolutny. Każda z Osób jest otwartością absolutną, która subsystuje w substancji absolutnej. Oznacza to, że substancja Boga jest otwarta, relacyjna. W tej wspólnej-jedynej i troistej otwartości zapisana jest też potencjalna otwartość na świat w jego całości i na poszczególne byty stworzone. Ślad (obraz) wewnątrz-Boskiej, trój-personalnej otwartości (heteroousía) znajduje się w poszczególnych bytach stworzonych, które są wszczepione w czas i przestrzeń. Bóg, który jest transcendentny, który nie jest niewolnikiem historii, stwarza historię, kieruje nią, wchodzi do jej wnętrza $^{21}$. Dzieje świata są odwzorowaniem a-czasowego działania dokonującego się wewnątrz Boga. Model trynitologiczny dla wyjaśnienia wychodzenia Boga na zewnątrz siebie, do świata (ex-systencja) i tworzenia dziejów świata, próbował zbudować Schelling, nawiązując do Anzelma z Aosty, a poprzez niego do Arystotelesa ${ }^{22}$. Schelling zarzucał myślicielom chrześcijańskim zdradę, ponieważ

20 Por. P. Liszka, Duch Święty twórcą Kościoła. Ujęciepersonalistyczne integralne, „Perspectiva”, 2 (2011), s. 177.

21 Por. F. Tomatis, Schelling: mysterium Trinitatis, [w:] P. Coda; A. Tapken (red.), La Trinità e il pensare. Figuri percorsi prospettive, Roma 1997, , s. 45.

22 Por. ibidem, s. 46. 
mówili o Bogu przeważnie w sposób ogólny, bez podkreślania trynitarności²3. Próbował on tworzyć model teologiczny, opisujący wieczną, wewnątrzboską teogonię, w której zawiera się zamysł stworzenia świata ${ }^{24}$. Próbował on tworzyć teologię integralną ${ }^{25}$.

Kwestia relacji Boga ze światem i kwestia przebóstwienia, były podejmowane w dziejach myśli chrześcijańskiej ${ }^{26}$. Dziś znaczna część refleksji teologicznych dotyczących relacji świata z Bogiem przeszła w obszar filozofii. Teologia powinna powrócić do metafizyki, korzystać z osiągnięć filozofii dawnej i nam współczesnej, ale na swój sposób, pamiętając o swoim zakresie badawczym, i o swoich metodach.

\section{Dążenie substancji bytów stworzonych i śladu Bożego w nich do swej pełni}

Byty stworzone przechodzą drogę od nicości do ostatecznego spełnienia na końcu czasów. Żydowski filozof Filon z Aleksandrii żyjący na tej Ziemi u zarania chrześcijaństwa, zastanawiał się nad pierwszymi efektami aktu stwórczego. Pod wpływem platonizmu mówił o ideach, które jednak nie znajdują się w jakimś nieokreślonym absolucie, lecz w Logosie, wewnątrz myśli Bożej. Wśród idei był nie tylko plan całego kosmosu, lecz również idea pustej przestrzeni. Przestrzeń bez obiektów jest czymś, co nie jest już nicością, ale nie jest jeszcze obiektem realnym ${ }^{27}$. W XX wieku pojawiła się koncepcja kosmicznej próżni, która jest odpowiednikiem pustej przestrzeni. Na wiele sposobów opisywany jest proces pojawiania się w niej coraz bardziej konkretnych bytów, od drgań kwantów, poprzez skumulowaną energię, aż do substancji materialnej. Tego rodzaju refleksje należą do sfery fizyki. Teologia zajmuje się tym, co trwa w świecie wskutek tego, że świat jest stworzony przez Boga. Poważną refleksję na ten temat podjął już w II wieku Orygenes, który podkreślał, że akt stwórczy jest bezczasowym czynem Boga, dokonującym się w wieczności życia Trójcy Świętej. Z tego wnioskował, że w każdej formie istnienia bytów stworzonych znajduje się w nich ślad Boga, który sprawia rozwój świata materialnego i duchowego,

\footnotetext{
$23 \quad$ Ibidem, s. 48.

24 Ibidem, s. 59.

25 Por. ibidem, s. 62.

26 Por. P. Nawara, Ksztattowanie się koncepcji przebóstwienia $(\theta \varepsilon \omega \sigma \iota \varsigma)$ w myśli teologiczno-filozoficznej wczesnego chrześcijaństwa, [w:] Studia z filozoficznej tradycji chrześcijaństwa, M. Manikowski (red.), Filozofia XXVIII, Wrocław 1998, 87-110, s. 104; Por. Maksym Wyznawca, Dialog o życiu wewnętrznym, 42.

27 Por. ibidem, s. 94.
} 
aż do sytuacji spełnienia po końcu świata, po Sądzie Ostatecznym ${ }^{28}$. W swej całości czas i rozwój świata ma charakter linearny. Wszelkie wirowania i zakrzywienia czasoprzestrzeni zmierzają konsekwentnie do punktu Omega, po którym nastanie nowa rzeczywistość. W przemienionym kosmosie ślad Boży zajaśnieje swą trynitarną pełnią.

Rozwój dotyczy nie tylko sfery materialnej, lecz nade wszystko sfery duchowej, której konstytutywnymi aspektami są intelekt, wola oraz uczucia. Wymiar rozwoju indywidualnego bytów personalnych sprzężony jest z wymiarem społecznym. Stopień rozwoju indywidualnego i społecznego współbrzmi ze stopniem rozwoju relacji z Bogiem Trójjedynym. Pełnia personalna jest równoważna z pełnią eklezjalną i z pełnym wszczepieniem w życie Osób Bożych ${ }^{29}$. Źródłem aktywności jednostkowej i społecznej jest jedność, i trynitarność Boga (2 Kor 1, 21-22; Gal 4, 4-7). Ostatecznym podłożem jest substancja Boga, a podmiotem nadającym kształt wszelkich bytów stworzonych są boskie energie personalne. Proces formacyjno-wspólnotowy będzie trwać do skończenia świata, a jego spełnieniem będzie Kościół niebiański w całej swojej pełni, jako zwieńczenie aktu stwórczego. Można powiedzieć, że cały kosmos, zbawiony wraz z ludźmi, zostanie wszczepiony w Boski czyn stwórczy, który jest źródłem i spełnieniem wszelkich bytów stworzonych.

Pomijamy tu kwestię możliwości niespełnienia wiecznego. W centrum uwagi jest to, że w sytuacji ostatecznego spełnienia substancje stworzone zachowają w pełni swoją tożsamość, autonomię, odrębność ontyczną, a jednocześnie będą znajdować się wewnątrz substancji Boga, która tym bardziej nie zmieni swej tożsamości: absolutnej, transcendentnej wobec stworzeń, nieskończenie od nich odrębnej. Zagadnienie to było przedmiotem refleksji od samego początku chrześcijaństwa. U poszczególnych myślicieli przeważał albo aspekt ontyczny, albo aspekt zbawczy. Wszyscy jednak byli przekonani o tym, że wszelkie byty stworzone mają w sobie ślad Boga, który przenika ich całość i prowadzi do sytuacji, w której wzajemne przenikanie substancji Boga z substancjami stworzonymi osiągnie pełnię, na miarę możliwości bytów stworzonych. Przenikanie substancji dokonuje się za pośrednictwem przenikania na poziomie energii. Ślad Boży to odwzorowanie przenikania trynitarnego, wewnątrz-Boskiego, w bytach stworzonych. Można powiedzieć, że byty stworzone są przenikane przez przenikanie wewnątrz-Boskie. W sytuacji ostatecznej owo przenikanie będzie maksymalne, a tym samym maksymalna będzie trynitarność wszelkich bytów.

\footnotetext{
28 Por. ibidem, s. 97.

29 Por. V. M. Pedrosa, Catequesis trinitaria, [w:] X. Pikaza, N. Silanes (red.), Diccionario..., s. 223.
} 
W szczególności narasta przebywanie w sobie nawzajem Boga i ludzi. Obecnie „trwamy w Nim, a On w nas, bo udzielił nam ze swego Ducha” (1 J 4, 13). Na końcu to wzajemne przenikanie osiągnie pełnię. Dla ludzi będzie to pełnia życia w Bogu, pełnia trynitarności i pełnia personalności. Na końcu spełnią się słowa Jezusa Chrystusa: „W owym dniu poznacie, że ja jestem w Ojcu moim, a wy we mnie i ja w was" (J 14, 20). Pełny sens będą miały słowa karmelitańskiej mistyczki, Elżbiety od Trójcy Świętej: „Trójca ta jest od dołu naszym klasztorem, naszym mieszkaniem, Nieskończonym, w którym możemy się poruszać wszędzie" ${ }^{30}$. Chrześcijanie powinni to sobie jasno uświadamiać i wspólpracować w dziele jednoczenia, gdyż sytuacja ostateczna jest tworzona przez Boga, ale zależy też od ludzi. Wspólpraca powinna być indywidualna i społeczna. Rosyjski myśliciel przełomu XIX i XX wieku, Mikołaj Fiodorow chciał, aby Trójca była programem społecznym w całym państwie. Jego idee inspirowały później myślicieli sowieckich, ale już w zupełnie innym charakterze, antyeklezjalnym, ateistycznym ${ }^{31}$. My wiemy, że prawdziwy Kościół jest z Trójcy Świętej, żyje w Bogu i prowadzi do pełni życia w niebie ${ }^{32}$. Dzieje kosmosu kształtowane są przez ślad Boży, zmierzając do ostatecznego spełnienia. Można powiedzieć, że dzieje kosmosu są cykliczne, wychodzą od zamysłu Bożego i wracają tam, w postaci realnej, konkretnej, zrealizowanej, pełnej. Początkiem oraz końcem jest Bóg - Alfa i Omega.

\section{Podsumowanie}

Przeprowadzona w artykule refleksja dotycząca śladu Bożego w stworzeniach ma charakter autorski, twórczy. Podporą są wybrane publikacje zajmujące się tym zagadnieniem, ale mogłyby być również wybrane zupełnie inne źródła i opracowania. Punkt ciężkości nie spoczywa na takich, czy innych źródłach, lecz na refleksji osobistej, samodzielnej. Ukazana została trynitarność śladu Boga w substancji bytów stworzonych niepersonalnych, a tym bardziej trynitarność obrazu Boga w bytach stworzonych personalnych. Źródłem istnienia stworzeń i źródłem śladu (obrazu) Bożego w nich jest Bóg Trójjedyny: substancja, trojaka specyfika personalna, relacje trynitarne, życie wewnętrzne Boga.

$30 \quad$ Zob. J.-P. Batut, Monarchia Ojca, porzadek pochodzen, perychoreza: trzy klucze teologiczne do poprawnego wyznawania wiary trynitarnej, [w:] Tajemnica Trójcy..., s. 334.

31 Por. B. Nichtweiss, Mysterium Trinitatis et Unitatis. Communauté et société à la lumière de la foi trinitaire et de la foi antitrinitaire, "Communio" 24 (1999) nr 5-6, s.; Zob. S. Siemionowa, Nikotaj Fiodorow. Tworczestwo żyzni, Moskwa 1990; Zob. A. Pomorski, Duchowy proletariusz. Przyczynek do dziejów lamarkizmu społecznego i rosyjskiego komunizmu XIX-XX wieku (na marginesie antyutopii Andrieja Płatonowa), Warszawa 1996.

32 H. de Lubac, Comment l'Église est-elle mystère?, [w:] Paradose et mystere de l'Église, Paris 1967, s. 49; Por. J.-P. Batut, Monarchia Ojca..., s. 335. 
Ślad (obraz) to pewien schemat, odwzorowanie, Boska pieczęć w stworzeniach, która nie jest w jakiejś części bytu stworzonego, lecz ogarnia go w całości, ogarnia jego wyposażenie wewnętrzne, a tym samym całą substancję.

Ślad (obraz) Boży tworzy relację między Bogiem a stworzeniami, jest z tą relację wewnętrznie sprzężony. To oznacza, że istnieje wzajemne przenikanie. Bóg jest w bytach stworzonych, a wszelkie byty są w Bogu. Wynika to z Objawienia, jako coś oczywistego. Teologia dąży do wyjaśnienia tego, w jaki sposób wzajemne przenikanie się dokonuje, co jest przyczyną (ostateczna i wtórną), jak się dokonuje i jaki jest ostateczny tego efekt. Zawarte w artykule przemyślenia mają charakter zalążkowy, pomagają w dalszych badaniach teologicznych nad tym zagadnieniem.

Słowa kluczowe: ślad Boga, obraz Boży, Bóg, stworzenia, substancja, relacja, trynitarność, rozwój, spełnienie.

\section{Bibliografia:}

1. Batut J.-P., Monarchia Ojca, porzadek pochodzen, perychoreza: trzy klucze teologiczne do poprawnego wyznawania wiary trynitarnej, [w:] Tajemnica Trójcy Świętej, Kolekcja „Communio" 13, Pallotinum 2000, s. 325-336.

2. Bayón A., La teología en la España de los siglos VIII-X, [w:] Historia de la Teología Española, t. 1: Desde sus orígenes hasta fines del siglo XVI, M. Andrés Martinez (red.), Fundación Universitaria Española: Seminario Suarez, Madrid 1983 s. 357407 (r. III.

3. Breuning W., Nauka o Bogu, Podręcznik Teologii Dogmatycznej. Traktat II, (red. W. Beinert), (oryginał: Gotteslehre, Ferdinand Schoningh Verlag, Paderborn 1995), wyd. M., Kraków 1999.

4. Capellini, André Neher e l'ermeneutica biblica, "Studia Patavina" 46 (1999) nr 1, s. $109-141$.

5. Ciola N., Teologia trinitaria. Storia-metodo-prospettive, „Nuovi Saggi Teologici” 39, Bologna 1996.

6. Ferrer Arellano J., Los dos manos del Padre. El doble movimiento de la alianza salvifica, en la misión conjunta e inseparabile del Verbo y del Espíritu Santo, como ,incarnatio in fieri", "Annales Theologici" 13 (1999) s. 3-70.

7. Krąpiec M. A., Analogia, [w:] Powszechna Encyklopedia Filozofii, t. 1, Lublin 2000, s. 210-220.

8. Liszka P., Duch Święty twórca Kościoła. Ujęcie personalistyczne integralne, "Perspectiva" (Legnickie Studia Teologiczno-Historyczne), 2 (2011), s. 174-183.

9. Lubac H. de, Comment l'Église est-elle mystère?, [w:] Paradose et mystere de l'Église, Paris 1967.

10. Margerie B. de, Osoba ludzka śladem, obrazem i podobieństwem Boga Trójcy, [w:] Tajemnica Trójcy Świętej, Kolekcja „Communio” 13, Pallotinum 2000, s. 388-395. 
11. Misiurek J., Antropomorfizm III. W teologii, [w:] Encyklopedia Katolicka, t. 1, F. Gryglewicz, R. Łukaszyk, Z. Sułowski (red.), Lublin 1985.

12. Muñiz Rodriguez V., Nombres de Dios, [w:] X. Pikaza, N. Silanes (red.), Diccionario Teológico. El Dios cristiano, Salamanca 1992, s. 970-975.

13. Nawara P., Kształtowanie się koncepcji przebóstwienia $(\theta \varepsilon \omega \sigma \iota \varsigma)$ w myśli teologiczno-filozoficznej wczesnego chrześcijaństwa, [w:] Studia z filozoficznej tradycji chrześcijaństwa, M. Manikowski (red.), Filozofia XXVIII, Wrocław 1998, s. 87-110.

14. Nichtweiss B., Mysterium Trinitatis et Unitatis. Communauté et société à la limière de la foi trinitaire et de la foi antitrinitaire, „Communio” 24 (1999) nr 5-6, s. 173-195.

15. Pedrosa V. M., Catequesis trinitaria, [w:] X. Pikaza, N. Silanes (red.), Diccionario Teológico. El Dios cristiano, Salamanca 1992, s. 222-244.

16. Pomorski A., Duchowy proletariusz. Przyczynek do dziejów lamarkizmu spolecznego i rosyjskiego komunizmu XIX-XX wieku (na marginesie antyutopii Andrieja Ptatonowa), Wydawnictwo Naukowe i Literackie, Warszawa 1996.

17. Silanes N., Misión, misiones, [w:] X. Pikaza, N. Silanes (red.), Diccionario Teológico. El Dios cristiano, Salamanca 1992, s. 879-890.

18. Siemionowa S., Nikołaj Fiodorow. Tworczestwo żyzni, Moskwa 1990.

19. Tomatis F., Schelling: mysterium Trinitatis, [w:] P. Coda; A. Tapken (red.), La Trinità e il pensare. Figuri percorsi prospettive, Città Nuova, Roma 1997, s. 45-64.

20. Uríbarri Bilbao G. SJ, Monarquia y Trinidad, Publicaciones de la Universidad Pontificia Comillas. Madrid, serie I: Estudios 62. wyd. UPCO (Universidad Pontificia Comillias), Madrid 1996. 